\title{
Type of financing dental care and frequency of dental visits among patients treated with implants
}

\begin{abstract}
Introduction. Many factors affect the oral health of the population. These include individual factors, the effectiveness of dental care, life styles and political, economic and environmental factors.

Aim. The aim of the study was to evaluate the type of financing dental care and frequency of dental visits among patients treated with implants because of missing teeth.

Material and methods. The survey was conducted among 464 patients of both genders aged 20-74 years, treated with dental implants at the Non-Public Healthcare Centre "Dental" in Tomaszów Mazowiecki. The patients answered questions included in anonymous questionnaire. The questions concerned age, education, type of dental care financing and frequency of dental visits.

Results. Results of the survey indicate that among patients treated with implants there were over 14-times more people benefiting from dental care in private clinics providing preventive and restorative treatments at full cost, compared with people using dental services funded by the National Health Fund. Just over $16 \%$ of the surveyed patients frequently enough, i.e. at least once in 6 months reported to the dentist. The frequency of dental visits increased with the education level - people with vocational and secondary education most often visited a dentist irregularly, when necessary, while those with higher education - once a year. Patients below 60 years reported to the dentist 1-2 times a year, whereas older - irregularly, when necessary.

Conclusion. In preparing the patient for the treatment of missing teeth with implants one should be aware of his need for paying special attention to oral health and regular, sufficiently frequent follow-up visits which has a substantial impact on the course and therapeutic success in the implant prosthetic treatment.
\end{abstract}

Keywords: dental implants, dental care, demographic factors.

DOI: $10.2478 /$ pjph-2014-0005

\section{INTRODUCTION}

Many factors influence oral health. These include individual factors, the effectiveness of dental care, life styles and political, economic and environmental factors [1]. It seems interesting to get to know some elements of dental care, demographic and social factors in a group of people who undertook paid treatment of missing teeth with implants.

\section{AIM}

The aim of the study was to evaluate the type of financing dental care and frequency of dental visits among patients treated with implants because of missing teeth.

\section{MATERIAL AND METHODS}

The survey was conducted among 464 patients of both genders aged 20-74 years, treated with dental implants at the Non-Public Healthcare Centre "Dental" in Tomaszów Mazowiecki. The patients answered questions included in anonymous questionnaire. Questions included age, education, type of funding dental care and frequency of visits to the dentist. The distributions of age and gender, age and education level of the respondents are presented in Table 1 and 2 . Using the $\chi 2$ test of independence the impact of the analyzed variables was analyzed. Statistical analysis was performed by using the Statistica 6.0 software (StatSoft, Inc., Tulsa, Oklahoma, USA).

\section{RESULTS}

It was found that the majority of patients treated with implants due to missing teeth made use of preventive therapeutic services of private dental offices at full-cost -434 people, representing $93.54 \%$ of the total respondents. Analysis of the effects of age and type of funding of dental care among the respondents showed that highly significantly more dental

\footnotetext{
${ }^{1}$ Chair and Department of Paedodontics, Medical University of Lublin, Poland

${ }^{2}$ Non-Public Healthcare Centre "Dental" in Tomaszów Mazowiecki, Poland

${ }^{3}$ Postgraduate trainee dentist; The Infant Jesus Teaching Hospital, Medical University of Warsaw, Poland
} 
TABLE 1. The gender and age of the patients treated for missing teeth with implants.

\begin{tabular}{lcccc}
\hline \hline \multirow{2}{*}{ Gender } & \multicolumn{3}{c}{ Age groups } & \multirow{2}{*}{ Total } \\
\cline { 2 - 4 } & $<40$ years & $40-60$ years & $>60$ years & \\
\hline \multirow{2}{*}{ Men } & 65 & 122 & 49 & 236 \\
\cline { 2 - 4 } & $27.54 \%$ & $51.69 \%$ & $20.76 \%$ & $100 \%$ \\
\hline \multirow{2}{*}{ Women } & 92 & 119 & 17 & 228 \\
\cline { 2 - 4 } Total & $40.35 \%$ & $52.19 \%$ & $7.46 \%$ & $100 \%$ \\
\hline
\end{tabular}

TABLE 2. The age and education of patients treated for missing teeth with implants.

\begin{tabular}{ccccc}
\hline \hline \multirow{2}{*}{ Age } & \multicolumn{3}{c}{ Education } & \multirow{2}{*}{ Total } \\
\cline { 2 - 4 } & Vocational & Secondary & Higher & \\
\hline \multirow{2}{*}{$<40$ years } & 5 & 51 & 101 & \multirow{2}{*}{157} \\
\cline { 2 - 4 } & $14.71 \%$ & $38.64 \%$ & $33.89 \%$ & \\
\hline \multirow{2}{*}{$40-60$ years } & 18 & 65 & 158 & \multirow{2}{*}{241} \\
\cline { 2 - 4 }$>60$ years & $52.94 \%$ & $49.24 \%$ & $53.02 \%$ & \\
\cline { 2 - 4 } & 11 & 16 & 39 & \multirow{2}{*}{464} \\
\cline { 2 - 4 } Total & $32.35 \%$ & $12.12 \%$ & $13.09 \%$ & \\
\cline { 2 - 4 } & 34 & 132 & 298 & $100 \%$ \\
\hline
\end{tabular}

TABLE 3. The age and the type of dental care financing among surveyed patients.

\begin{tabular}{|c|c|c|c|}
\hline \multirow{2}{*}{ Age } & \multicolumn{2}{|c|}{ Dental care } & \multirow{2}{*}{ Total } \\
\hline & NHF & Private dental office & \\
\hline \multirow{2}{*}{$<40$ years } & 2 & 155 & \multirow{2}{*}{157} \\
\hline & $6.67 \%$ & $35.71 \%$ & \\
\hline \multirow{2}{*}{$40-60$ years } & 18 & 223 & \multirow{2}{*}{241} \\
\hline & $60.00 \%$ & $51.38 \%$ & \\
\hline \multirow{2}{*}{$>60$ years } & 10 & 56 & \multirow{2}{*}{66} \\
\hline & $33.33 \%$ & $12.90 \%$ & \\
\hline \multirow{2}{*}{ Total } & 30 & 434 & \multirow{2}{*}{464} \\
\hline & $100 \%$ & $100 \%$ & \\
\hline
\end{tabular}

The value of the test function $\chi 2=15.562, \mathrm{p}=0.0004$

TABLE 4. The age and frequency of dental visits among surveyed patients.

\begin{tabular}{ccccc}
\hline \hline \multirow{2}{*}{ Age } & \multicolumn{3}{c}{ Frequency of dental visits } & \multirow{2}{*}{ Total } \\
\cline { 2 - 4 } & $\begin{array}{c}\text { At least once } \\
\text { in } 6 \text { months }\end{array}$ & $\begin{array}{c}\text { Once } \\
\text { a year }\end{array}$ & $\begin{array}{c}\text { Irregularly, } \\
\text { when necessary }\end{array}$ & \\
\hline \multirow{2}{*}{$<40$ years } & 33 & 89 & 35 & 157 \\
\cline { 2 - 4 } & $21.02 \%$ & $56.69 \%$ & $22.29 \%$ & $100 \%$ \\
\hline $40-60$ years & 36 & 103 & 102 & 241 \\
\cline { 2 - 4 }$>60$ years & $14.94 \%$ & $42.74 \%$ & $42.32 \%$ & $100 \%$ \\
\cline { 2 - 4 } & $10.61 \%$ & $37.88 \%$ & $51.52 \%$ & $100 \%$ \\
\hline Total & 76 & 217 & 171 & 464 \\
\hline
\end{tabular}

The value of the test function $\chi 2=24.937, \mathrm{p}<0.001$ services funded by the National Health Fund (NHF) were used by people between 40 and 60 years of age and over 60 years, and patients aged up to 40 years - more frequently made use of services in private dental offices at full cost $(\mathrm{p}<0.001)$ (Table 3$)$.

Just over $16 \%$ of surveyed patients, i.e. 76 subjects reported at least once in six months to the dentist. Analysis by age and frequency of dental visits among patients treated for missing teeth with implants indicates that the frequency of visits to the dentist was highly significantly influenced by age $(p<0.001)$. Patients under the age of 60 years reported to the dentist often enough, while people over the age of 60 did so irregularly, if necessary (Table 4).

The impact of education and type of funding of dental care of patients surveyed are presented in Table 5. Among patients who received implants significantly more people with vocational education benefit from dental services paid by the National Health Fund, and the patients with higher education - made use of services in private clinics at full $\operatorname{cost}(\mathrm{p}<0.001)$.

The impact of education and frequency of dental visits of patients treated for missing teeth with implants is shown in Table 6. The frequency of reporting to the dentist of patients surveyed highly statistically significant depends on education $(p<0.001)$. It increases with education level. People with vocational and secondary education most often visited a dentist irregularly, if necessary, while those with higher education - once a year.

TABLE 5. Education and type of funding of dental care of patients surveyed.

\begin{tabular}{|c|c|c|c|}
\hline \multirow{2}{*}{ Age } & \multicolumn{2}{|c|}{ Dental care } & \multirow{2}{*}{ Total } \\
\hline & NHF & Private practice & \\
\hline \multirow{2}{*}{ Vocational } & 7 & 27 & 157 \\
\hline & $20.59 \%$ & $79.41 \%$ & $100 \%$ \\
\hline \multirow{2}{*}{ Secondary } & 13 & 119 & 241 \\
\hline & $9.85 \%$ & $90.15 \%$ & $100 \%$ \\
\hline \multirow{2}{*}{ Higher } & 10 & 288 & 66 \\
\hline & $3.36 \%$ & $96.64 \%$ & $100 \%$ \\
\hline Total & 30 & 434 & 464 \\
\hline
\end{tabular}

TABLE 6. Education and frequency of dental visits among the patients surveyed.

\begin{tabular}{lcccc}
\hline \hline \multirow{2}{*}{ Age } & \multicolumn{3}{c}{ Frequency of visits at the dentist } & \\
\cline { 2 - 4 } & $\begin{array}{c}\text { At least once } \\
\text { in } 6 \text { months }\end{array}$ & $\begin{array}{c}\text { Once } \\
\text { a year }\end{array}$ & $\begin{array}{c}\text { Irregularly, } \\
\text { when necessary }\end{array}$ & \\
\hline \multirow{2}{*}{ Vocational } & 7 & 4 & 23 & 34 \\
\cline { 2 - 4 } & $20.59 \%$ & $11.76 \%$ & $67.65 \%$ & $100 \%$ \\
\hline \multirow{2}{*}{ Secondary } & 16 & 49 & 67 & 132 \\
\cline { 2 - 4 } & $12.12 \%$ & $37.12 \%$ & $50.76 \%$ & $100 \%$ \\
\hline \multirow{2}{*}{ Higher } & 53 & 164 & 81 & 298 \\
\cline { 2 - 4 } & $17.79 \%$ & $55.03 \%$ & $27.18 \%$ & $100 \%$ \\
\hline Total & 76 & 217 & 171 & 464 \\
\hline & The value of the test function $\gamma 2=41.313, \mathrm{p}<0.001$ &
\end{tabular}

The value of the test function $\chi^{2}=41.313, \mathrm{p}<0.001$ 


\section{DISCUSSION}

Our studies show that regardless of age, among patients treated with implants there were14-times more people who benefited from dental care in private clinics providing preventive and restorative treatments at full cost, compared with the patients making use of dental services that were funded by the National Health Fund. This is undoubtedly related to the financial capabilities of the respondents, as shown in an earlier publication [2]. It seems clear that due to the high cost of implant prosthetic treatment, recipients of the treatment procedures are the better-off people, better educated, or those whose financial status is usually higher. It is also a group of patients who can afford using other dental procedures at full cost.

Oboda provides that according to $90 \%$ of dentists only $10-30 \%$ of patients are aware of their dental needs, $50 \%$ do not complete undertaken treatment and only $20 \%$ of patients report to follow-up visits [3]. Similarly, only a small group of people in our study - a little over $16 \%$ of respondents reported to the dentist at least once in six months. It is noted that frequent check-up visits are respectively one of the essential elements of the prevention of dental caries and periodontal disease.

The studies of other authors show that the main reason for delay in dental visits among patients of the age group 35-44 years is the fear of dental surgery $(59.1 \%)$. Further reasons given by patients included lack of concern about the state of their teeth (45\%) and dissatisfaction with dental care covered by the National Health Fund (40.9\%). In the cited studies, there were no statistically significant differences in socioeconomic status and education between people not delaying and delaying visits to the dentist [4]. In turn, the research carried out in the Krakow research centre has shown that health behaviors and self-assessment of oral health are associated with dental anxiety and sociodemographic factors [5].

Implementation of the recommendations of the dentist, regular visits and maintenance of oral hygiene at a high level ensures successful implant reconstruction for many years [6]. Patients should be aware that the implantoprosthetic procedure does not end with the placement of restoration. It is recommended that the first year after implant-based reconstruction tartar should be professionally removed every 3 months [7]. During these visits, in addition to carrying out specialized hygienic procedures, it is possible to control hygiene procedures carried out by the patient at home [8].

\section{CONCLUSION}

In conclusion it should be noted that while preparing the patient to implant prosthetic treatment, the patient should be made aware of his/her need for paying special attention to oral health and regular, sufficiently frequent follow-up visits which have a substantial impact on the course of treatment and therapeutic success.

\section{REFERENCES}

1. Szatko F. Prace nad poprawą zdrowia jamy ustnej i rozwojem opieki stomatologicznej w Polsce. Społeczno-ekonomiczne uwarunkowania stanu zdrowotnego jamy ustnej polskiego społeczeństwa. Czas Stomatol. 1999;52(8):546-54.

2. Szymańska J, Koszuta A. The influence of selected demographic and socioeconomic factors on patient's decision-making about the treatment of missing teeth using the implants. Curr Issues Pharm Med Sci. 2013;26(4):418-21.

3. Oboda M. Rola i znaczenie kształtowania świadomości pacjenta w rozwoju praktyki. Implantologia Stomatol. 2011;2:62-4.

4. Kulawiak M, Bachanek T. Przyczyny odkładania wizyt stomatologicznych przez pacjentów $\mathrm{z}$ grupy wiekowej 35-44 lata w województwie lubelskim. Mag Stomatol. 2013;9:187-93.

5. Olszewska-Czyż I, Domiszewska D, Pasierb L, Chomyszyn-Gajewska M. Analiza zachowań prozdrowotnych oraz samooceny zdrowia i higieny jamy ustnej pacjentów dorosłych w aspekcie lęku stomatologicznego oraz determinant socjodemograficznych. Mag Stomatol. 2013;12:129. 36.

6. Majewski S. Podstawowe wiadomości na temat badania, diagnostyki i kwalifikowania pacjentów do leczenia impalntoprotetycznego. Implantoprotetyka. 2005;6(2):32-50.

7. Pawlik M. O ryzyku periimplantitis. Sztuka Implantologii 2009;2:44-8.

8. Koczorowski R, Pawlik M. Higiena jamy ustnej u pacjentów leczonych implantoprotetycznie. e-Dentico. 2011;2(30):28-40.

\section{Corresponding author}

Jolanta Szymańska

Chair and Department of Paedodontics,

Medical University of Lublin

7 Karmelicka Str., 20-081 Lublin, Poland

E-mail: szymanska.lublin@gmail.com 